\title{
Preparation of a sugarcane bagasse-based substrate for second- generation ethanol: Effect of pasteurisation conditions on dephenolisation
}

\author{
Enrique González-Bautista ${ }^{\text {a, b }}$, Enrique Alarcón-Gutiérrez ${ }^{\text {b }}$, Nathalie Dupuy ${ }^{\text {a }}$, \\ Isabelle Gaime-Perraud ${ }^{\text {a }}$, Fabio Ziarelli ${ }^{\mathrm{c}}$, Lisa Foli ${ }^{\mathrm{a}}$, Anne-Marie Farnet-Da-Silva ${ }^{\text {a, * }}$ \\ a Aix Marseille Université, CNRS, IRD, Avignon Université, IMBE UMR, 7263, Marseille, France \\ ${ }^{\mathrm{b}}$ Universidad Veracruzana, Instituto de Biotecnología y Ecología Aplicada (INBIOTECA), Campus para La Cultura, Las Artes y El Deporte, Av. de Las Culturas \\ Veracruzanas No. 101 Col. Emiliano Zapata, C.P. 91090, Xalapa, Veracruz, Mexico \\ ${ }^{\mathrm{c}}$ Aix Marseille Université, CNRS, Spectropole Campus St Jérôme, Fédération des Sciences Chimiques de Marseille, FR 1739, 13397, Marseille, France
}

Keywords:

Heat pre-treatment

Lignocellulose transformation

Solid-state fermentation

White-rot fungi

Laccase

\begin{abstract}
Second-generation ethanol process uses lignocellulose, but a pre-treatment is required to degrade lignin before saccharification. Biological pre-treatment, using phenoloxidases, represents a cheap and ecofriendly option. Mould contamination can be overcome by heat pre-conditioning of substrates. Pasteurisation can be a mild and sustainable option. A 5-level response-surface experimental design was performed to test the effect of different time and temperatures on lignocellulolytic activities and substrate dephenolisation. Substrate microbial communities were characterised via catabolic profiles to determine functional diversity changes after pasteurisation. Temperatures ranging from 70 to $75{ }^{\circ} \mathrm{C}$ and time from 5 to $10 \mathrm{~h}$ led to the highest laccase activities and 30\% of substrate dephenolisation was achieved while avoiding mould contamination. The per cent of O-Alkyl (polysaccharides) did not vary significantly, meaning that polysaccharides were not extensively consumed. Microbial communities were less catabolically diversified $\left(H^{\prime}=1.2\right)$ but more active $(A W C D=0.9)$ and could degrade polysaccharides.
\end{abstract}

\section{Introduction}

Production of bioethanol from lignocellulose usually includes three major steps: pre-treatment of the substrate (dephenolisation), saccharification and fermentation [1]. Of all these steps, pretreatment represents a bottleneck because of high-energy consumption and environmental concerns due to the use of hazardous compounds [2]. Many chemical, physical and biological approaches have been tested for pre-treatment [3]. Biological or enzymatic pretreatments can be considered as a sustainable option, requiring no hazardous chemicals, low energy input and mild operating conditions [4]. Biological pre-treatment uses phenoloxidases like laccases (benzenediol: oxygen oxidoreductase, EC 1.10.3.2), which are responsible for lignin degradation in soils and litters. These enzymes are mainly produced by white-rot fungi [5] and present some advantages: they catalyse a broad range of phenolic substrates (low specificity), do not need co-factors and have high catalytic efficiency. All these properties make them useful for a variety of industrial and environmental applications including aromatic compound transformation (bio-bleaching, bioconversion) or bio-detoxification (bioremediation and effluent treatment) [6,7]. Eventhough enzymatic pre-treatment presents some advantages, low rates of lignin oxidation become a challenge to obtain a sustainable process [8]. Interestingly, the white-rot fungus Pycnoporus sanguineus produces high amounts of laccases as the main ligninolytic enzymes, including induced and constitutive isoforms, making it interesting for industrial applications [9-11].

To enhance dephenolisation of lignocellulose, a heat-treatment has to be implemented to limit contamination by moulds. Moreover, heat-treatment can improve enzymatic digestibility of lignocellulose fibres by cellulases, phenol-oxidases and other enzymatic activities [12]. During heat-treatment, lignocellulosic biomass is heated from 150 to $180{ }^{\circ} \mathrm{C}$ to solubilize hemicelluloses and lignin [13]. Nevertheless, at these temperatures, inhibitory compounds like phenolic compounds, furfural or hydroxyl-methyl-furfural can be produced. These compounds can affect the fermentation of 
monosaccharides into ethanol and reduce overall yields [14]. An alternative for this process is steam explosion treatment, which combines high temperature $\left(250^{\circ} \mathrm{C}\right)$ and pressure for a short period (from 2 to $5 \mathrm{~min}$ ), limiting inhibitory compound production [12]. However, both methodologies require special equipments that endure high pressure and temperature and high-energy consumption increases production costs.

Pasteurisation represents a cheaper, milder and more ecological option compared to other thermal treatments $[15,16]$. Pasteurisation can open lignocellulose fibres thus enhancing substrate colonisation and degradation by white-rot fungi [16]. Different conditions of pasteurisation for lignocellulosic substrates have been reported with temperatures ranging from 60 to $80{ }^{\circ} \mathrm{C}$ for $2-24 \mathrm{~h}$. Depending on pasteurisation conditions, different groups of microorganisms can be selected [17]. For instance, thermotolerant microbial communities can actively colonise lignocellulose after pasteurisation and contribute to polysaccharide degradation favouring lignin availability [18]. Moreover, substrate microbial communities can limit mould contamination and also have antagonistic interactions with Pycnoporus sanguineus, which can potentially induce laccase production $[19,20]$. White-rot fungi can indeed over-produce laccases during these interactions, which is considered as a mechanism of defence against antifungal metabolites produced by substrate microbial communities [21]. There are some reports of thermotolerant bacteria in lignocellulosic substrates that can enhance laccase production such as Bacillus spp. [19,22] This increase in laccase production can contribute to enhancing substrate dephenolisation.

The current study aims to determine adequate conditions of thermal treatment (temperature and time) which could limit contaminations, favour Pycnoporus sanguineus colonisation and thus eventually dephenolisation of the substrate. This study would thus help to define suitable conditions for pre-treatment of sugarcane bagasse (SCB). This lignocellulosic substrate is one of the most produced world wide, reaching 42.8 million tons in 2010 [11]. SCB is rich in cellulose $(\approx 50 \%)$ and has high glucan digestibility (47\%) [23]. Consequently, SCB is considered as a cheap source of polysaccharides that can be hydrolysed and then fermented into ethanol [11]. Moreover, this substrate has been complemented with coffee pulp which has been proved to induce laccase activities under such solid-state fermentation conditions [11]. To do so, a response-surface experimental design was set up to test the effects of time and temperature of pasteurisation on laccase and cellulase activities and transformation of lignocellulose via solid-state ${ }^{13} \mathrm{C}$ CP/MAS NMR (Cross Polarization at Magic Angle Spinning Nuclear Magnetic Resonance). Moreover, substrate microbial communities were characterised via catabolic profiles by Biolog EcoPlate ${ }^{\mathrm{TM}}$ to determine variations of functional diversity of the communities depending on pasteurisation conditions.

\section{Materials and methods}

\subsection{White-rot fungal strain and inoculum preparation}

The strain of Pycnoporus sanguineus used was isolated from a wild mushroom found in the sugar-cane fields of Jalcomulco, Veracruz, Mexico (19 20 '00' ' $\mathrm{N}, 96^{\circ} 46^{\prime} 00$ 'W), registered as $\mathrm{F}$. Ramírez-Guillén 932 in the XAL herbarium (INECOL, A.C.) and identified by analysis of ITS fragments 1 and 4 (Access Genebank KR013138). Five agar pieces ( $1 \mathrm{~cm}$ diameter), after seven days of growth on malt extract agar $(20 \mathrm{~g} / \mathrm{L})$, were used as inoculum of wheat grains in glass plates: $150 \mathrm{~mL}$ of water and $0.5 \mathrm{~g}$ of gypsum were added to $100 \mathrm{~g}$ of wheat grains and sterilized by autoclaving [24]. Then, the plates were incubated ten days at $30^{\circ} \mathrm{C}$ [11].

\subsection{Mesocosm preparation}

SCB complemented with $10 \%$ of coffee pulp, used as an inductor of laccase [11,25], which was previously milled and sterilized twice by autoclave. Dried and milled SCB (particles from 0.5 to $3 \mathrm{~cm}$ ) were received from Mahuixtlán sugar refinery, located at Mahuixtlán, Veracruz, Mexico. The composition of this by-product was analysed by ${ }^{13} \mathrm{C} \mathrm{CP/MAS} \mathrm{NMR} \mathrm{by} \mathrm{Hernández} \mathrm{et} \mathrm{al.} \mathrm{[24]:} \mathrm{O-Alkyl-C} \mathrm{79.76 \% ,}$ aromatics $12.87 \%$, $\mathrm{COOH}-\mathrm{C} 3.57 \%$ and Alkyl-C $2.45 \%$. The coffee pulp was obtained from a shade-grown commercial coffee culture with the dominant variety Coffea arabica [26], located in the Tlacontla farm, San Marcos de León, municipality of Xico, Veracruz, Mexico. Mesocosms were inoculated with Pycnoporus sanguineus with $5.0 \%$ of dry weight (DW). Each mesocosm was set up in $0.5 \mathrm{~L}$ crystal plates $\left(10 * 14 * 5 \mathrm{~cm}^{3}\right)$, covered with an aluminium foil. For each treatment, three replicates were made, to obtain a total of 27 mesocosms which were incubated at $30^{\circ} \mathrm{C}$ at $80 \%$ of the WHC in the dark for 60 days.

\subsection{Experimental design}

An experimental design was performed using, as independent variables, the pasteurisation time and temperature, using 5 levels each and a full-cubic model (Table 1 ). Time of pasteurisation ranged from 1 to $24 \mathrm{~h}(1,4,12,20$ and $24 \mathrm{~h})$ and temperature from 55 to $80{ }^{\circ} \mathrm{C}\left(55,58,67,76\right.$ and $\left.78{ }^{\circ} \mathrm{C}\right)$. These conditions were selected according to previous studies on pasteurisation of lignocellulosic materials [20,22]. The dependent variables measured were laccase and cellulase activities, chemical properties of the substrate by solid-state ${ }^{13} \mathrm{C} \mathrm{CP} / \mathrm{MAS}$ NMR and catabolic profiles of bacterial communities by Biolog EcoPlate ${ }^{\mathrm{TM}}$.

\subsection{Lignocellulolytic activities}

Laccases were quantified according to Farnet et al. [27], with syringaldazine ( $15 \mu \mathrm{M}$ in methanol) as substrate. Cellulase activity was assayed using Carboxy-Methylcellulose (CMC) at $1 \%$ as substrate according to the Somogyi-Nelson method modified by Farnet et al., [28]. One unit (U) of enzyme activities is defined as one $\mu$ mole of the reaction product formed per $\mathrm{h}$ and per $\mathrm{g}$ of Dried Weight.

\subsection{Solid-state ${ }^{13} \mathrm{C} C P / M A S N M R$}

The chemical composition of SCB, of coffee pulp and of the substrate at t0 was characterised by solid-state ${ }^{13} \mathrm{C} \mathrm{CP/MAS} \mathrm{NMR,}$ on a spectrophotometer Bruker DSX $400 \mathrm{MHz}$ operating at 100.7 MHz. Samples (400 mg) were spun at $10 \mathrm{kHz}$ at the magic angle. Contact times of $2 \mathrm{~ms}$ were applied with a pulse width of 2.8 $\mu \mathrm{s}$ and a recycle delay of $3 \mathrm{~s}$. Chemical shift values were referenced to tetra-methyl-silane and calibrated to glycine carbonyl signal set at $176.03 \mathrm{ppm}$. The relative $\mathrm{C}$ distribution in ${ }^{13} \mathrm{C}$ NMR spectra was determined by integrating the signal intensity in different chemical shift regions [29], with an integration routine supplied with Dmfit 2003 software. Seven common chemical shift regions were defined according to Mathers and $\mathrm{Xu}$ [30]. The crystallinity of cellulose was measured according to Park et al. [31].

\subsection{Microbial catabolic profiles}

Microbial catabolic profiles were assessed using Biolog EcoPlate $^{\mathrm{TM}}$. Each 96-well plate contained three replicates with 31 sole carbon sources and water blank for each one. Ten grams of mesocosm at $80 \%$ of humidity was vigorously shaken in $100 \mathrm{~mL}$ of a sterilized desorption-solution $(\mathrm{NaCl}, 0.08 \mathrm{~g} / \mathrm{L})$ for $1 \mathrm{~h}$ and then brought to a final OD $=0.005$ at $595 \mathrm{~nm}$. A $150 \mu \mathrm{L}$ aliquot of the 
Table 1

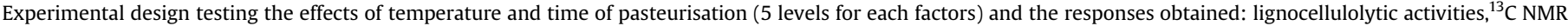
signals and H', Shannon-Weaver index of catabolic diversity, AWCD, Average Well Colour Development, R, Richness, number of substrates used from Biolog data.

\begin{tabular}{|c|c|c|c|c|c|c|c|c|c|c|c|c|c|}
\hline \multicolumn{3}{|c|}{ Pasteurisation conditions } & \multicolumn{2}{|c|}{ Enzymatic activities } & \multicolumn{6}{|l|}{${ }^{13} \mathrm{C}$ NMR } & \multicolumn{3}{|c|}{$\begin{array}{l}\text { Microbial catabolic } \\
\text { profiles }\end{array}$} \\
\hline Conditions & Temperature $\left({ }^{\circ} \mathrm{C}\right)$ & Time $(\mathrm{h})$ & Laccase (U) & Cellulase (U) & Total aromatics & O-Alkyl & Aromatic ratio & Alkyl/COOH & Crystalline rate & Alkyl-C & $\mathrm{H}^{\prime}$ & AWCD & Richness \\
\hline 1 & 76 & 20 & 0.65 & 28.21 & 10.26 & 79.65 & 0.11 & 1.28 & 0.23 & 3.68 & 2.86 & 0.26 & 10.0 \\
\hline 1 & 76 & 20 & 0.60 & 35.24 & 9.89 & 79.11 & 0.10 & 1.36 & 0.24 & 4.47 & 3.08 & 0.27 & 15.0 \\
\hline 1 & 76 & 20 & 0.55 & 31.52 & 8.30 & 81.22 & 0.09 & 1.57 & 0.23 & 4.44 & 2.76 & 0.42 & 18.0 \\
\hline 2 & 67 & 24 & 0.38 & 160.43 & 10.07 & 77.78 & 0.10 & 1.54 & 0.24 & 4.99 & 2.88 & 0.24 & 14.0 \\
\hline 2 & 67 & 24 & 0.16 & 195.37 & 7.42 & 80.89 & 0.08 & 1.80 & 0.25 & 5.50 & 2.50 & 0.29 & 30.0 \\
\hline 2 & 67 & 24 & 0.24 & 173.51 & 8.61 & 78.98 & 0.09 & 1.61 & 0.22 & 5.49 & 2.48 & 0.49 & 25.0 \\
\hline 3 & 80 & 12 & 0.01 & 32.50 & 9.73 & 77.79 & 0.10 & 1.48 & 0.23 & 5.23 & 2.54 & 0.30 & 11.0 \\
\hline 3 & 80 & 12 & 0.11 & 42.18 & 8.32 & 77.07 & 0.09 & 2.39 & 0.22 & 7.05 & 2.16 & 0.12 & 6.0 \\
\hline 3 & 80 & 12 & 0.02 & 45.86 & 8.82 & 77.35 & 0.09 & 1.71 & 0.24 & 6.26 & 2.58 & 0.32 & 13.0 \\
\hline 4 & 58 & 4 & 0.01 & 10.42 & 9.53 & 78.72 & 0.10 & 1.48 & 0.20 & 4.73 & 1.76 & 0.07 & 1.0 \\
\hline 4 & 58 & 4 & 0.02 & 11.81 & 9.81 & 79.02 & 0.10 & 1.52 & 0.20 & 4.47 & 1.87 & 0.04 & 1.0 \\
\hline 4 & 58 & 4 & 0.10 & 12.84 & 9.34 & 79.45 & 0.10 & 1.80 & 0.20 & 4.74 & 1.96 & 0.03 & 1.0 \\
\hline 5 & 76 & 4 & 0.32 & 53.00 & 7.39 & 80.70 & 0.08 & 1.55 & 0.23 & 5.42 & 2.55 & 0.43 & 28.0 \\
\hline 5 & 76 & 4 & 0.32 & 53.25 & 7.64 & 80.01 & 0.08 & 1.44 & 0.26 & 5.57 & 2.00 & 0.65 & 29.0 \\
\hline 5 & 76 & 4 & 0.32 & 53.00 & 7.39 & 80.27 & 0.08 & 1.50 & 0.26 & 5.79 & 1.45 & 0.92 & 27.0 \\
\hline 6 & 67 & 12 & 0.65 & 69.03 & 8.51 & 79.50 & 0.09 & 1.37 & 0.25 & 5.14 & 2.49 & 0.42 & 29.0 \\
\hline 6 & 67 & 12 & 0.56 & 87.49 & 8.93 & 79.48 & 0.09 & 1.52 & 0.23 & 4.85 & 1.94 & 0.52 & 27.0 \\
\hline 6 & 67 & 12 & 0.77 & 75.00 & 7.63 & 81.08 & 0.08 & 1.36 & 0.25 & 4.83 & 1.45 & 0.25 & 29.0 \\
\hline 7 & 55 & 12 & 0.07 & 8.23 & 9.36 & 79.70 & 0.10 & 1.39 & 0.22 & 4.38 & 1.63 & 0.05 & 2.0 \\
\hline 7 & 55 & 12 & 0.08 & 10.61 & 9.12 & 79.96 & 0.09 & 1.69 & 0.21 & 4.42 & 1.71 & 0.30 & 8.0 \\
\hline 7 & 55 & 12 & 0.09 & 27.28 & 9.28 & 77.91 & 0.10 & 2.13 & 0.20 & 6.25 & 1.35 & 0.05 & 6.0 \\
\hline 8 & 67 & 1 & 0.27 & 18.02 & 9.69 & 78.95 & 0.10 & 1.37 & 0.22 & 4.41 & 2.30 & 0.51 & 20.0 \\
\hline 8 & 67 & 1 & 0.27 & 22.67 & 9.78 & 78.96 & 0.10 & 1.54 & 0.20 & 4.58 & 1.84 & 0.52 & 28.0 \\
\hline 8 & 67 & 1 & 0.20 & 20.91 & 10.75 & 79.19 & 0.11 & 1.01 & 0.20 & 3.40 & 1.18 & 0.27 & 10.0 \\
\hline 9 & 58 & 20 & 0.10 & 6.98 & 10.84 & 78.18 & 0.11 & 1.32 & 0.20 & 4.17 & 2.30 & 0.16 & 15.0 \\
\hline 9 & 58 & 20 & 0.14 & 4.84 & 10.61 & 79.01 & 0.11 & 1.13 & 0.22 & 3.95 & 1.78 & 0.38 & 27.0 \\
\hline 9 & 58 & 20 & 0.14 & 7.28 & 9.57 & 80.65 & 0.10 & 1.30 & 0.21 & 3.70 & 1.45 & 0.24 & 13.0 \\
\hline
\end{tabular}

extracted solution was added to each of the 96 wells in a Biolog ${ }^{\circledR}$ EcoPlate (Biolog, California, USA). The plates were incubated at $30{ }^{\circ} \mathrm{C}$ for $24 \mathrm{~h}$ and the absorbance was read at $590 \mathrm{~nm}$ using a microplate reader (Metertech $\sum 960$, Avantec, France). The functional diversity was assessed by Shannon's diversity index $\left(\mathrm{H}^{\prime}\right)$ [32,33] from $\mathrm{H}^{\prime}=-\sum$ pi (ln pi), where pi is the ratio of colour development of well " $\mathrm{i}$ " to the sum of colour development of all positive wells. This index gives information about the functional diversity of substrate microbial community. The global activity of these communities was assessed as the average well-colour development (AWCD) calculated as follows: AWCD $=\sum \mathrm{ODi} / 31$, where ODi is the optical density for each well (i). Richness, R, was calculated as the number of substrates used, which informs about the catabolic potential of the substrate microbial communities.

\subsection{Statistical analyses}

Correlations between variables and the factors tested were determined using UNSCRAMBLER-X $10 * 3$ (CAMO). To find out whether the independent factors have significant effects on each

Table 2

Two-way ANOVA testing the effect of temperature and time of pasteurisation on lignocellulosic activities, chemical properties and catabolic diversity.

\begin{tabular}{llll}
\hline Response & Model check & P-value & F ratio \\
\hline Laccase activity & Cubic model & $<0.001$ & 18.45 \\
Cellulase activity & Cubic model & $<0.001$ & 23.14 \\
Crystallinity & Cubic model & $<0.005$ & 7.01 \\
O-Alkyl & Cubic model & $<0.05$ & 3.4 \\
Total aromatics & Cubic model & $<0.001$ & 10.91 \\
Aromatic ratio & Cubic model & $<0.001$ & 9.81 \\
Alkyl-C & Cubic model & $<0.005$ & 6.87 \\
$\mathrm{H}^{\prime}$ & Interaction & $<0.05$ & 0.14 \\
AWCD & Interaction & $<0.002$ & 2.84 \\
\hline
\end{tabular}

response, a two-way ANOVA was carried out (Table 2). Homoscedasticity and normality were analysed previously. The interaction effects of time and temperature of pasteurisation were analysed by response surface methodology [34]. Pearson's correlation coefficients were calculated among all the NMR peaks from the 27 mesocosms after 60 days of incubation.

\section{Results}

\subsection{Effect of different pasteurisation conditions on dephenolisation of sugarcane bagasse}

Results obtained for laccase and cellulase activities are shown in Table 1. Analysing the surface plot for laccase activity ("Cubic model" $P<0.001$, Table 2 ), we observed that the range of temperatures from 70 to $75{ }^{\circ} \mathrm{C}$ and time from 10 to $18 \mathrm{~h}$ of pasteurisation favoured laccase activities (up to $0.8 \mathrm{U} / \mathrm{g}$ DW) of Pycnoporus sanguineus (Fig. 1A). On the other hand, it is worth noticing that pasteurisation at low temperatures whatever the time used and pasteurisation at high temperatures $\left(76-80{ }^{\circ} \mathrm{C}\right)$ for short time (1-5 h), limited laccase activities of Pycnoporus sanguineus. Thus, there are very specific conditions of pasteurisation that enhance laccase activities during solid-state fermentation.

Cellulase activity surface plot ("Cubic model" $P<0.001$, Table 2) showed that there were two conditions of pasteurisation that enhanced such activities. The first conditions which led to higher cellulase activities (up to $160 \mathrm{U} / \mathrm{g}$ DW) were $24 \mathrm{~h}$ of pasteurisation, no matter the temperature used. The second condition which favoured cellulase activities but to a lesser extent (around $98 \mathrm{U} / \mathrm{g} \mathrm{DW}$ ), were temperatures ranging from 64 to $73{ }^{\circ} \mathrm{C}$ and time ranging from 5 to $10 \mathrm{~h}$ (Fig. 1B).

Substrate chemical modifications were followed by solid-state ${ }^{13} \mathrm{C} \mathrm{CP} / \mathrm{MAS}$ NMR and results obtained are shown in Table 1 . Total aromatics decreased up to $30 \%$, compared to control at t0, for 

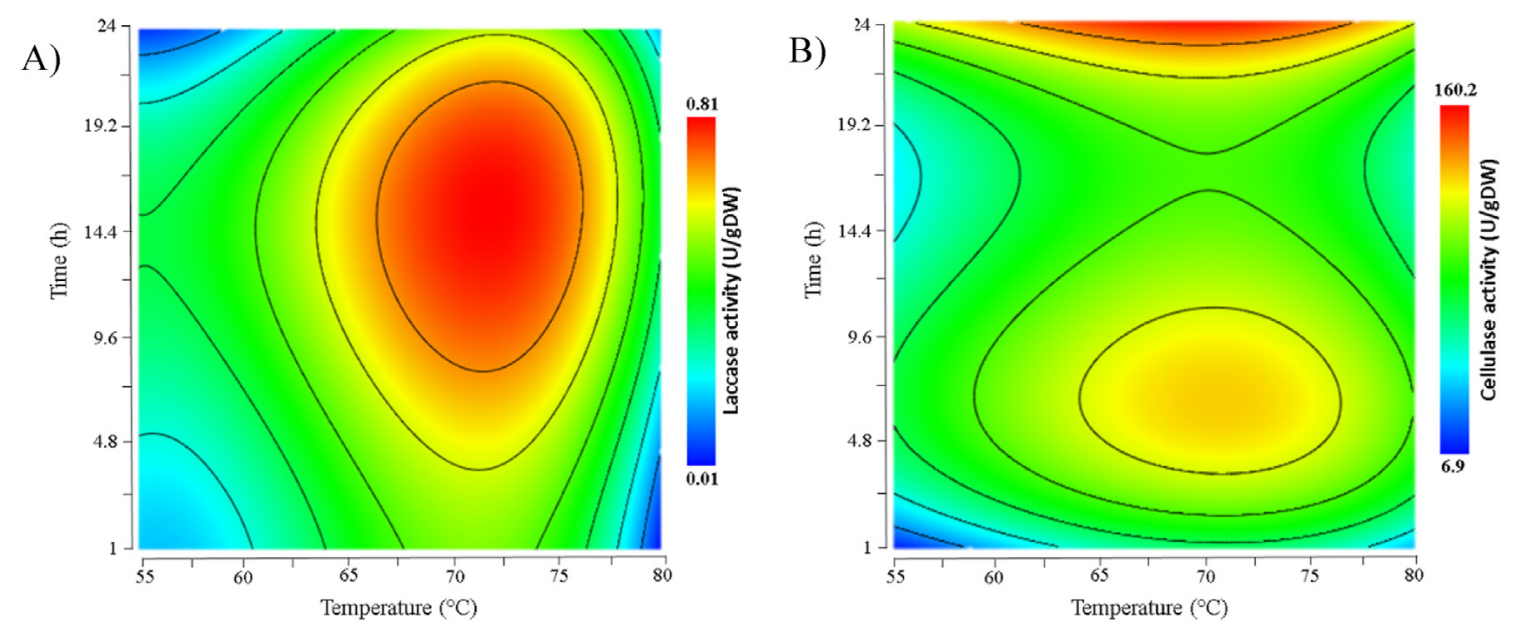

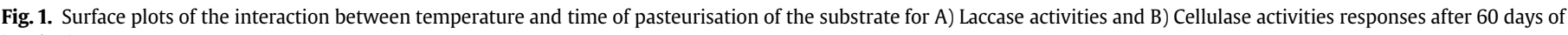
incubation.

temperatures ranging from 70 to $75^{\circ} \mathrm{C}$ and for time ranging from 5 to $10 \mathrm{~h}$ ("Cubic model" $P<0.001$, Table 2, Fig. 2A). Under these pasteurisation conditions, total aromatics were reduced from 11.66 to $6.97 \%$. This tendency was also observed for the Aromaticity ratio ("Cubic model" $P<0.001$, Table 2 ) for the same ranges of temperatures and time. It has to be noted that this range of temperatures (from 65 to $75^{\circ} \mathrm{C}$ ) overlapped with those where high laccase activities were observed (Fig. 1A). On the other hand, a high proportion of aromatics was found for low temperatures and short time of pasteurisation (Fig. 2A) and this also corresponded to pasteurisation conditions where laccase activities were low.

For O-Alkyl signal (a marker of polysaccharides), the surface plots revealed significant differences ("Cubic model" $P<0.05$, Table 2, Fig. 2B). Low O-Alkyl percentages were observed for high temperatures $\left(80^{\circ} \mathrm{C}\right)$ whatever the time of pasteurisation. On the other hand, high O-Alkyl percentages were found for temperatures ranging from 70 to $75{ }^{\circ} \mathrm{C}$ whatever the time of pasteurisation. Interestingly, the ranges of temperature and time (from 70 to $75^{\circ} \mathrm{C}$ and from 5 to $10 \mathrm{~h}$ ) favouring cellulases were similar to those where a higher crystallinity ratio (crystalline vs amorphous cellulose) around 26\% ("Cubic model" $P<0.005$, Table 2) was found (Fig. 3A). This reveals that for these conditions, the more available fraction of polysaccharides ('amorphous cellulose') was consumed.

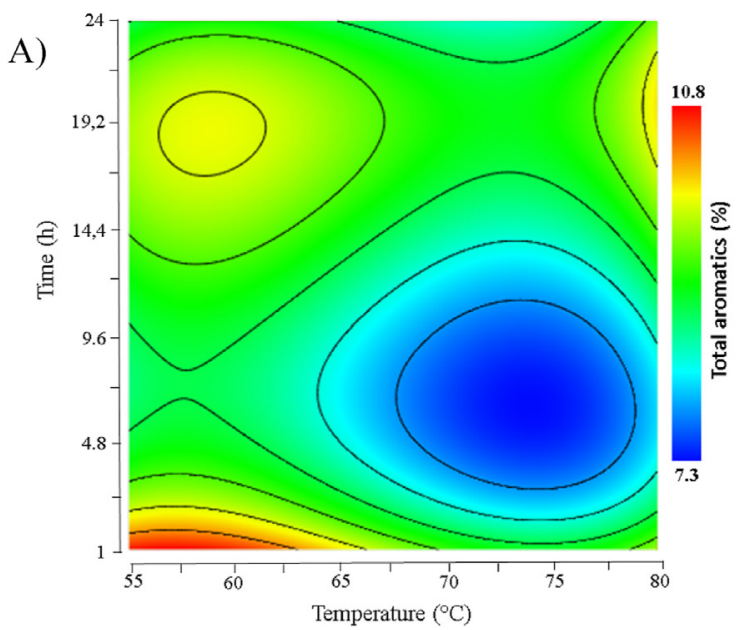

Thus, temperatures from 70 to $75{ }^{\circ} \mathrm{C}$ and time from 5 to $10 \mathrm{~h}$ favoured high lignocellulolytic activities (laccases and cellulases), led to a low amount in total aromatics and a high crystallinity index. This corresponds to the responses required for a suitable substrate pre-treatment. Moreover, no visual contaminations by moulds were observed in the mesocosms using these conditions of pasteurisation.

At high temperatures $\left(80^{\circ} \mathrm{C}\right)$ and short time of pasteurisation (5-10 h), Alkyl-C surface plots ("Cubic model" $P<0.005$, Table 2, Fig. 3B) showed higher amounts of these compounds (6.65\%) compared to other pasteurisation conditions (Fig. 3).

\subsection{Variation in catabolic diversity of bacterial communities of the substrate depending on pasteurisation conditions}

The Shannon-Weaver diversity index $\left(\mathrm{H}^{\prime}\right)$, Richness, $\mathrm{R}$, (number of substrates used) and average well colour development (AWCD) were calculated from Biolog data to analyse the catabolic diversity, the potential of substrate utilisation and global activity of substrate microbial communities after different pasteurisation conditions. All the results are shown in Table $1 . \mathrm{H}^{\prime}$ surface plot ("Interaction model" $P<0.05$, Table 2 ) indicated that microbial communities in the substrate exhibited a high catabolic diversity when high

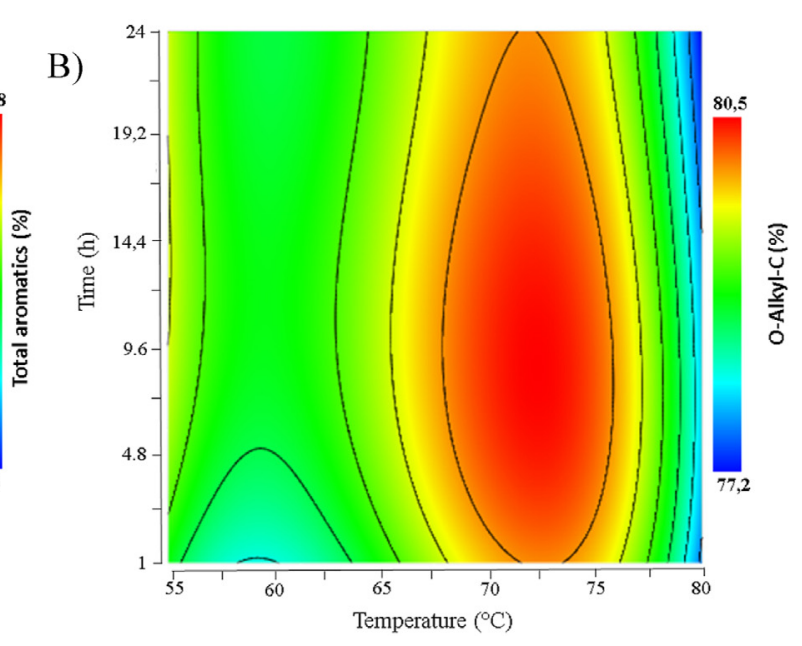

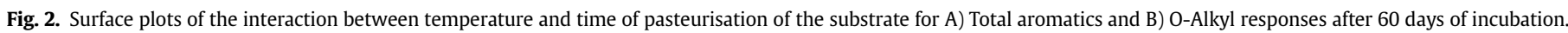



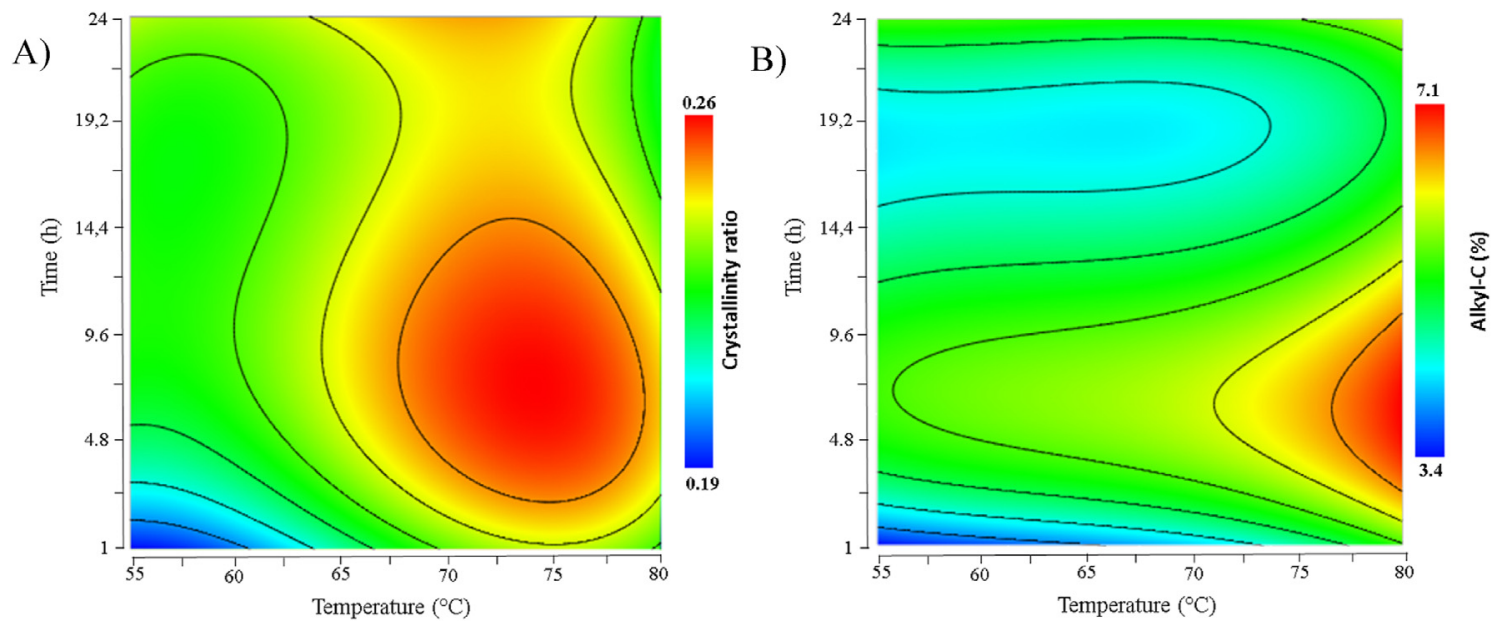

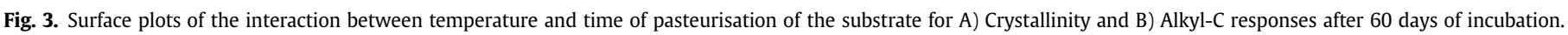

temperatures $\left(80^{\circ} \mathrm{C}\right)$ and long time of pasteurisation $(24 \mathrm{~h})$ were used $\left(\mathrm{H}^{\prime}=3.6\right)$ (Fig. 4A). On the other hand, low levels of catabolic diversity (from 1.54 to 2 ) were obtained for low temperatures $\left(55^{\circ} \mathrm{C}\right)$ and pasteurisation time ranging from 6 to $20 \mathrm{~h}$. Thus, for those ranges of temperature and time where dephenolisation was high (i.e. $70-75^{\circ} \mathrm{C}$ and $\left.5-10 \mathrm{~h}\right), \mathrm{H}^{\prime}$ was low $\left(\mathrm{H}^{\prime}=2.0\right)$. Moreover, for these conditions and though substrate consumption richness was high (28 of 31 substrates consumed), the main carbon sources catabolised (OD > 0.3) were specifically related to cellulose and hemicellulose decomposition (D-cellobiose, D-mannitol and Dxylose), or pectin (D-galacturonic acid) and other types of sugar (Lerythritol).

Conversely, the surface plot of AWCD showed an opposite tendency compared to H' ("Interaction model" $P<0.002$, Table 2) (Fig. 4B). AWCD was relatively high $(\mathrm{OD}=0.73$ ) for time ranging from 1 to $5 \mathrm{~h}$ of pasteurisation and for temperatures ranging from 70 to $75{ }^{\circ} \mathrm{C}$. It is noteworthy that a relatively high AWCD (OD around 0.53 ) was found under the same pasteurisation conditions as those favouring laccase activities and dephenolisation of the substrate. It seems that long time of pasteurisation and high temperatures increased $\mathrm{H}^{\prime}$ value while leading to relatively low AWCD. On the other hand, for short time of pasteurisation and high temperatures, the index of diversity, H' was lower, and AWCD was high.

\section{Discussion}

Our results showed that high temperatures $\left(70-75^{\circ} \mathrm{C}\right)$ and short time (5-10 h) of pasteurisation enhanced laccase activities and favoured a decrease in the aromatic fraction of the substrate, revealing that these specific pasteurisation conditions were suitable for dephenolisation. High laccase activities, observed after these pasteurisation conditions, could be related to two different phenomena. First, the thermotolerant microflora of the substrate selected after pasteurisation may develop an antagonist interaction with Pycnoporus sanguineus. There is evidence that, in lignocellulosic material like sugarcane bagasse, high temperatures of pasteurisation can select thermotolerant microorganisms like Bacillus sp. [35-37]. According to literature, this microbial selection could be beneficial for dephenolisation, since this bacterial genus has been proved to interact with white-rot fungi and to enhance laccase activities via antagonism [19,21]. Secondly, phenolic compounds from coffee pulp can enhance laccase activities [11]. During pasteurisation, phenolic compounds, commonly found in coffee pulp, such as ferulic, caffeic, coumaric or chlorogenic acids can be released into the substrate [37]. Temperatures around $80{ }^{\circ} \mathrm{C}$ can enhance the extraction of phenolic compounds [38], and since these molecules are like-laccase substrates, they can induce the
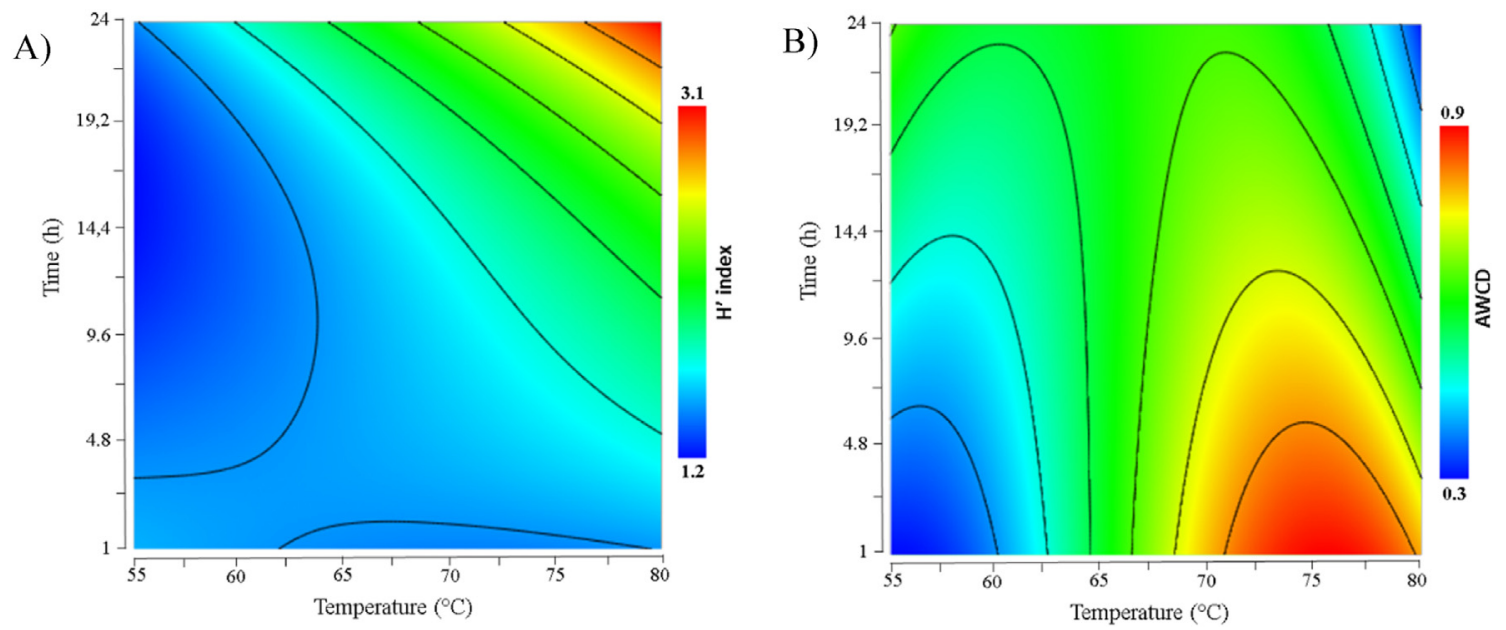

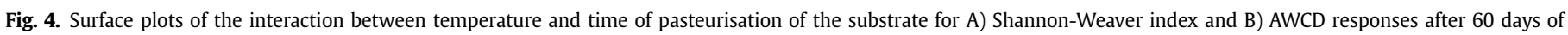
incubation. 
production of these enzymes $[39,40]$. On the other hand, certain pasteurisation conditions (mainly low temperatures) did not favour laccases. Low laccase activities can be linked to low fungal growth of Pycnoporus sanguineus. The production of these enzymes is indeed characteristic of white-rot fungi and thus, these enzymes can be considered as a biological marker of white-rot fungus development [41]. Moreover, decrease in laccase activities at low temperature and short time of pasteurisation, can be linked to a weaker extraction of aromatics from coffee pulp that can act as laccase inducers as described above.

Pasteurisation conditions linked to more intense dephenolisation (high temperature, short time) also led to an increase in cellulase activities together with high crystallinity index. High cellulase activities can favour lignin oxidation since hydrolysis of polysaccharide fibres makes lignin more available $[42,43]$. Synergetic mechanisms between cellulases and laccases have indeed been described. The intricate matrix of cellulose, hemicellulose and lignin requires a multi-enzymatic action to be degraded significantly [44]. Crystallinity index increase can be explained by the fact that cellulose degradation has been proven to begin with consumption of amorphous regions, where polysaccharides are more available for enzymatic hydrolysis [45-48]. Hernández et al. [24], also observed similar results: crystallinity index increased after solid-state fermentation of SCB using Pycnoporus sanguineus and the authors also concluded that the amorphous cellulose fraction of substrate was first consumed by fungal enzymes.

On the other hand, low crystallinity was observed at lower temperatures and short time of pasteurisation and this can be related to low lignocellulolytic activities and high aromatic proportions. Thus, all these chemical and enzymatic markers indicate that these pasteurisation conditions led to a weak degradation of lignocellulosic substrate [49].

High cellulase activities were also observed for other pasteurisation conditions characterised by a long time of pasteurisation $(22-24 \mathrm{~h})$ and a wide range of temperatures $\left(61-78^{\circ} \mathrm{C}\right)$. This can be linked to the observed contamination of the substrate by moulds after these pasteurisation conditions. This group of fungi is known to actively produce cellulases, which can explain the increase in such activities [50]. Moreover, during long-lasting pasteurisation, high temperatures probably provoked modifications in fibre structure, increasing the surface of colonisation, making the fibres more available for degradation by cellulolytic microorganisms [51]. Moulds are fast-growing fungi that can overpass the potential of colonisation of white-rot fungi such as Pycnoporus sanguineus [19]. For example, mesocosms pasteurized at $76^{\circ} \mathrm{C}$ for $20 \mathrm{~h}$ or at $80^{\circ} \mathrm{C}$ for $12 \mathrm{~h}$ were contaminated by moulds around 15 days after incubation, inhibiting the growth of the white-rot fungus (Table 3 ). On the other hand, mesocosms pasteurized at $76{ }^{\circ} \mathrm{C}$ for $4 \mathrm{~h}$ were colonized by Pycnoporus sanguineus only, requiring up to 45 days for complete coverage of the substrate. This means that short pasteurisation time at high temperatures has crucial effects to avoid contaminations by fast-growing moulds and favour the white-rot fungus growth. This goes in line with previous reports where high temperature $\left(80^{\circ} \mathrm{C}\right)$ and short time of pasteurisation ( $2 \mathrm{~h}$ ) were used [52], to limit substrate contaminations.

Alkyl-C signal is usually related to lipids and thus to phospholipids from fungal biomass under solid-state fermentation conditions [53]. However, here, an increase in Alkyl-C at high temperatures $\left(80^{\circ} \mathrm{C}\right)$ and a short time of pasteurisation $(5-10 \mathrm{~h})$ was not connected with markers of fungal growth such as lignocellulolytic activities, which decreased for those conditions of pasteurisation [11].

To characterise the catabolic potential of microbial communities of the substrate, H'index, AWCD and catabolic richness were determined. $\mathrm{H}^{\prime}$ index increased at high temperature and long time of pasteurisation, indicating that microbial communities were functionally diversified. This can be related to low selectivity of thermotolerant microorganisms like Bacillus spp. after pasteurisation under these conditions. Vieira and Pecchia [20] observed that relative abundance of Bacillae -in wheat straw-based substratepasteurized at low temperature $\left(57^{\circ} \mathrm{C}\right)$, decreased. Gram-positive bacteria such as Bacillus spp. and Actinobacteria spp. became dominant after high-temperature pasteurisation $\left(68{ }^{\circ} \mathrm{C}\right)$ [17]. Moreover, increasing temperature and time of pasteurisation can make the substrate more accessible to the hydrolysis potential of diverse microorganisms, which proliferate in the substrate [12]. On the other hand, low $\mathrm{H}^{\prime}$ observed at low temperature and time between 6 and $20 \mathrm{~h}$ of pasteurisation, strengthened the fact that temperature is a determinant factor that controls the diversity of substrate microbial communities after pasteurisation [20].

Conversely, AWCD was low when $\mathrm{H}^{\prime}$ was high, showing that eventhough microbial communities were functionally diverse, they were less metabolically active. On the other hand, high AWCD but low $\mathrm{H}^{\prime}$ were observed for pasteurisation conditions where laccases, cellulases and dephenolisation were favoured (from 5 to $10 \mathrm{~h}$ and temperatures from 70 to $75^{\circ} \mathrm{C}$ ). Similar results were obtained by Feng et al. [54], who found a negative correlation between catabolic diversity index, $\mathrm{H}^{\prime}$ and lignin degradation from lignocellulosic materials (wheat straw). Phenol oxidation leads to the release of polysaccharide-derived products from the lignocellulosic matrix [55] and thus selects microorganisms with specific enzymatic activities like cellulases or xylanases [56]. Thus, it seems that, for these pasteurisation conditions, certain microorganisms specialised in sugar oxidation were selected, leading to a low index of catabolic diversity H'. Moreover, this specialization of substrate bacterial communities can be beneficial for the degradation of polysaccharides during the further saccharification step.

\section{Conclusion}

High temperature $\left(70-75^{\circ} \mathrm{C}\right)$ and short time $(5-10 \mathrm{~h})$ of pasteurisation limited contaminations by fast-growing moulds,

Table 3

Mould contaminations and Pycnoporus sanguineus growth observed in the mesocosms during the fermentation after different pasteurisation conditions.

\begin{tabular}{|c|c|c|c|c|}
\hline Condition & Temperature $\left({ }^{\circ} \mathrm{C}\right)$ & Time $(\mathrm{h})$ & Mould contamination & Pycnoporus sanguineus growth \\
\hline 1 & 76 & 20 & $\mathrm{xx}$ & $\mathrm{x}$ \\
\hline 2 & 67 & 24 & $\mathrm{xxx}$ & $\mathrm{x}$ \\
\hline 3 & 80 & 12 & $\mathrm{xx}$ & $\mathrm{x}$ \\
\hline 4 & 58 & 4 & No contamination & $\mathrm{x}$ \\
\hline 5 & 76 & 4 & No contamination & $\mathrm{xxx}$ \\
\hline 6 & 67 & 12 & No contamination & $\mathrm{x}$ \\
\hline 7 & 55 & 12 & No contamination & $\mathrm{x}$ \\
\hline 8 & 67 & 1 & No contamination & $\mathrm{x}$ \\
\hline 9 & 58 & 20 & No contamination & $\mathrm{xx}$ \\
\hline
\end{tabular}

Low $(\mathrm{X})$ medium $(\mathrm{XX})$ and high $(\mathrm{XXX})$ mould contamination or white-rot fungus growth (visual observations). 
meanwhile, $30 \%$ of substrate dephenolisation was achieved. Under these pasteurisation conditions, laccase activities of Pycnoporus sanguineus were enhanced, which can be linked to the reduction observed in total aromatics. Moreover, these pasteurisation conditions selected thermotolerant bacterial communities from the substrate. These bacterial communities were able to actively produce specific enzymes related to degradation of lignocellulose polysaccarides, which can be beneficial for lignin availability and also for the further saccharification step and overall bioethanol production. Further studies should aim at screening and identifying thermotolerant bacteria with antagonistic effects against Pycnoporus sanguineus, which may enhance laccase production of the white-rot fungus.

\section{Acknowledgments}

The authors are grateful to the National Council of Science and Technology (CONACYT) of Mexico, for the doctoral scholarship of Enrique González Bautista no. 440596 and to ECOS-ANUIES-CONACYT Program through the ECOS project M13A02, for financial support. We would like to thank Mimi Colletin for providing us wheat grains for fungal cultures.

\section{References}

[1] N. Mosier, Features of promising technologies for pre-treatment of lignocellulosic biomass, Bioresour. Technol. 96 (2005) 673-686.

[2] A. Das, C. Mondal, S. Roy, Pre-treatment methods of ligno-cellulosic biomass: a review, J. Eng. Sci. Technol. Rev. 8 (2015) 141-165.

[3] A.W. Bhutto, K. Qureshi, K. Harijan, R. Abro, T. Abbas, A.A. Bazmi, G. Yu, Insight into progress in pre-treatment of lignocellulosic biomass, Energy 122 (2017) $724-745$.

[4] M. Bilal, M. Asgher, H.M. Iqbal, H. Hu, X. Zhang, Biotransformation of lignocellulosic materials into value-added products- A review, Int. J. Biol. Macromol. 98 (2017) 447-458.

[5] J.W. Lee, K.S. Gwak, J.Y. Park, M.J. Park, D.H. Choi, M. Kwon, I.G. Choi, Biological pre-treatment of softwood Pinus densiflora by three white rot fungi, J. Microbiol. 45 (2007) 485-491.

[6] A.M. Farnet, G. Gil, F. Ruaudel, A.C. Chevremont, E. Ferre, Polycyclic aromatic hydrocarbon transformation with laccases of a white-rot fungus isolated from a Mediterranean schlerophyllous litter, Geoderma 149 (2009) 247-271.

[7] Z. Wang, J. Liu, Y. Ning, X. Liao, Y. Jia, Eichhornia crassipes: agro-waster for a novel thermostable laccase production by Pycnoporus sanguineus SYBC-L1, J. Biosci. Bioeng. 123 (2017) 163-169.

[8] P. Kumar, D.M. Barrett, M.J. Delwiche, P. Stroeve, Methods for pretreatment of lignocellulosic biomass for efficient hydrolysis and biofuel production, Ind. Eng. Chem. Res. 48 (2009) 3713-3729.

[9] O. Fokina, J. Eipper, L. Winandy, S. Kerzenmacher, R. Fischer, Improving the performance of a biofuel cell cathode with laccase-containing culture supernatant from Pycnoporus sanguineus, Bioresour. Technol. 175 (2015) 445-453.

[10] A.L. Zimbardi, P.F. Camargo, S. Carli, S. Aquino Neto, L.P. Meleiro, J. Rosa, R.P. Furriel, A high redox potential laccase from Pycnoporus sanguineus RP15: potential application for dye decolorization, Int. J. Mol. Sci. 17 (2016) 672.
[11] E. Bautista-Gonzalez, E. Gutierrez-Alarcon, N. Dupuy, I. Gaime-Perraud, F. Ziarelli, A.M. Farnet da Silva, Pre-treatment of a sugarcane bagasse-based substrate prior to saccharification: effect of coffee pulp and urea on laccase and cellulase activities of Pycnoporus sanguineus, J. Environ. Int. J. Environ. Manage. 239 (2019) 178-186.

[12] A.T.W.M. Hendriks, G. Zeeman, Pretreatments to enhance the digestibility of lignocellulosic biomass, Bioresour. Technol. 100 (2009) 10-18.

[13] G.D.H.P. Garrote, H. Dominguez, J.C. Parajo, Hydrothermal processing of lignocellulosic materials, Eur. J. Wood. Wood. Prod. 57 (1999) 191-202.

[14] M. Laser, D. Schulman, S.G. Allen, J. Lichwa, M.J. Antal Jr., L.R. Lynd, A comparison of liquid hot water and steam pretreatments of sugar cane bagasse for bioconversion to ethanol, Bioresour. Technol. 81 (2002) 33-44.

[15] R. Singh, A. Shukla, S. Tiwari, M. Srivastava, A review on delignification of lignocellulosic biomass for enhancement of ethanol production potential, Renew. Sustain. Energy Rev. 32 (2014) 713-728.

[16] M. Saritha, A. Arora, Biological pretreatment of lignocellulosic substrates for enhanced delignification and enzymatic digestibility, Indian J. Microbiol. 52 (2012) 122-130.

[17] P. Partanen, J. Hultman, L. Paulin, P. Auvinen, M. Romantschuk, Bacterial diversity at different stages of the composting process, BMC Microbiol. 10 (2010) 94.

[18] J.M. Savoie, G. Mata, The antagonistic action of Trichoderma sp. hyphae to Lentinula edodes hyphae changes lignocellulotytic activities during cultivation in wheat straw, World J. Microbiol. Biotechnol. 15 (1999) 369-373.

[19] M. Velázquez-Cedeño, A.M. Farnet, G. Mata, J.M. Savoie, Role of Bacillus spp. in antagonism between Pleurotus ostreatus and Trichoderma harzianum in heattreated wheat-straw substrates, Bioresour. Technol. 99 (2008) 6966-6973.

[20] F.R. Vieira, J.A. Pecchia, An exploration into the bacterial community under different pasteurization conditions during substrate preparation (Composting-Phase II) for Agaricus bisporus cultivation, Microb. Ecol. 75 (2018) $318-330$.

[21] J.D. Crowe, S. Olsson, Induction of laccase activity in Rhizoctonia solani by antagonistic Pseudomonas fluorescens strains and a range of chemical treatments, Appl. Environ. Microbiol. 67 (2001) 2088-2094.

[22] M. Velázquez-Cedeño, A.M. Farnet, E. Ferré, J.M. Savoie, Variation of lignocellulosic activities in dual cultures of Pleurotus ostreatus and Trichoderma longibrachiatum on unsterilized wheat straw, Mycologia 96 (2004) 712-719.

[23] H. Zabed, J. Sahu, A. Suely, A. Boyce, G. Faruq, Bioethanol production from renewable sources: current perspectives and technological progress, Renew. Sustain. Energy Rev. 71 (2017) 475-501.

[24] C. Hernández, A.M.F. Da Silva, F. Ziarelli, I. Perraud-Gaime, B. Gutiérrez-Rivera, J.A. García-Pérez, E. Alarcón, Laccase induction by synthetic dyes in Pycnoporus sanguineus and their possible use for sugar cane bagasse delignification, Appl. Microbiol. Biotechnol. 101 (2017) 1189-1201.

[25] T.K. Bhat, B. Singh, O.P. Sharma, Microbial degradation of tannins-a current perspective, Biodegradation 9 (1998) 343-357.

[26] P. Moguel, V.M. Toledo, Biodiversity conservation in traditional coffee systems of Mexico, Conserv. Biol. 13 (1999) 11-21.

[27] A.M. Farnet, L. Qasemian, F. Peter-Valence, F. Ruaudel, J.M. Savoie, S. Roussos, É. Ferré, Do spawn storage conditions influence the colonization capacity of a wheat-straw-based substrate by Agaricus subrufescens? C. R. Biol. 337 (2014) 443-450.

[28] A.M. Farnet, L. Qasemian, D. Guiral, E. Ferré, A modified method based on arsenomolybdate complex to quantify cellulase activities: application to litters, Pedobiologia 53 (2010) 159-160.

[29] D. Massiot, F. Fayon, M. Capron, I. King, S. Le Calvé, B. Alonso, G. Hoatson, Modelling one-and two-dimensional solid-state NMR spectra, Magn. Reson. Chem. 40 (2002) 70-76.

[30] N.J. Mathers, Z. Xu, Solid-state ${ }^{13}$ C NMR spectroscopy: characterization of soil organic matter under two contrasting residue management regimes in a 2year-old pine plantation of subtropical Australia, Geoderma 114 (2003) $19-31$.

[31] J.W. Park, H.W. Kang, B.S. Ha, S.I. Kim, S. Kim, H.S. Ro, Strain-dependent response to $\mathrm{Cu}^{2+}$ in the expression of laccase in Pycnoporus coccineus, Arch. Microbiol. 197 (2015) 589-596.

[32] C.E. Shannon, T. Weaver, A mathematical theory for communication, Bell Labs Tech. J. 27 (1949) 379-423.

[33] J.C. Zak, M.R. Willig, D.L. Moorhead, H.G. Wildman, Functional diversity of microbial communities: a quantitative approach, Soil Biol. Biochem. 26 (1994) $1101-1108$

[34] G.E. Box, K.B. Wilson, On the Experimental Attainment of Optimum Conditions, Breakthroughs in Statistics, Springer, 1992, pp. 270-310.

[35] M.F. Ghaly, E.M. Abdellah, Optimization of cellulase (s) and xylanase production by thermophilic and alkaliphilic Bacillus isolates, Am.-Eurasian J. Agric. Environ. Sci. 13 (2013) 553-564.

[36] R. Arora, S. Behera, S. Kumar, Bioprospecting thermophilic/thermotolerant microbes for production of lignocellulosic ethanol: a future perspective, Renew. Sustain. Energy Rev. 51 (2015) 699-717.

[37] M.T. Torres-Mancera, J. Cordova-López, G, Rodríguez-Serrano, S. Roussos, M.A. Ramírez-Coronel, E. Favela-Torres, G. Saucedo-Castañeda, Enzymatic extraction of hydroxycinnamic acids from coffee pulp, Food Technol. Biotechnol. 49 (2011) 369-373.

[38] A. Gramza, J. Korczak, R. Amarowicz, Tea polyphenols-their antioxidant properties and biological activity-a review, Pol. J. Food Nutr. Sci. 14 (2005) 219-235. 
[39] A.M. Farnet, S. Criquet, E. Pocachard, G. Gil, E. Ferre, Effect of an induced laccase on aromatic compounds. Purification of a new isoform of laccase from a Marasmius quercophilus strain isolated from a cork oak litter (Quercus suber L.), Mycologia 94 (2002) 735-740.

[40] L. Qasemian, D. Guiral, M. Belghazi, E. Ferré, R. Gros, A.M. Farnet, Identification of various laccases induced by anthracene and contribution to its degradation in a Mediterranean coastal pine litter, Chemosphere 84 (2011) 1321-1328.

[41] R. Zhuo, L. Ma, F. Fan, Y. Gong, X. Wan, M. Jiang, Y. Yang, Decolorization of different dyes by a newly isolated white-rot fungi strain Ganoderma sp. En3 and cloning and functional analysis of its laccase gene, J. Hazard Mater. 192 (2011) 855-873.

[42] F.A. Perras, H. Luo, X. Zhang, N.S. Mosier, M. Pruski, M.M. Abu-Omar, Atomiclevel structure characterization of biomass pre-and post-lignin treatment by dynamic nuclear polarization-enhanced solid-state NMR, J. Phys. Chem. 121 (2017) 623-630.

[43] K.K. Prasad, S.R. Chaganti, S.V. Mohan, P.N. Sarma, Solid state fermentation of laccase from new pulse husks: process optimization and bioprocess study, IJIBCS 2 (2011) 22-34.

[44] R. Sindhu, P. Binod, A. Pandey, Biological pretreatment of lignocellulosic biomass-An overview, Bioresour. Technol. 199 (2016) 76-82.

[45] E. González-Bautista, J.C. Santana-Morales, F.J. Ríos-Fránquez, H.M. PoggiVaraldo, A.C. Ramos-Valdivia, E. Cristiani-Urbina, T. Ponce-Noyola, Phenolic compounds inhibit cellulase and xylanase activities of Cellulomonas flavigena PR-22 during saccharification of sugarcane bagasse, Fuel 196 (2017) 32-35.

[46] Q. Chen, M.N. Marshall, S.M. Geib, M. Tien, T.L. Richard, Effects of laccase on lignin depolymerization and enzymatic hydrolysis of ensiled corn stover, Bioresour. Technol. 117 (2012) 186-192.

[47] Z. Yu, K.S. Gwak, T. Treasure, H. Jameel, H.M. Chang, S. Park, Effect of lignin chemistry on the enzymatic hydrolysis of woody biomass, ChemSusChem 7 (2014) 1942-1950.

[48] C. Howell, A.C.S. Hastrup, B. Goodell, J. Jellison, Temporal changes in wood crystalline cellulose during degradation by brown-rot fungi, Int. Biodeterior Biodegrad. 63 (2009) 414-419.

[49] X.Q. Dong, J.S. Yang, N. Zhu, E.T. Wang, H.L. Yuan, Sugarcane bagasse degradation and characterization of three white-rot fungi, Bioresour. Technol. 131 (2013) 443-451.

[50] B. Singh, M.J. Poças-Fonseca, B.N. Johri, T. Satyanarayana, Thermophilic molds: biology and applications, Crit. Rev. Microbiol. 42 (2016) 985-1006.

[51] P. Widsten, A. Kandelbauer, Adhesion improvement of lignocellulosic products by enzymatic pre-treatment, Biotechnol. Adv. 26 (2008) 379-386.

[52] D. Salvachúa, R. Katahira, N.S. Cleveland, P. Khanna, M.G. Resch, B.A. Black A.T. Martínez, Lignin depolymerization by fungal secretomes and a microbial sink, Green Chem. 18 (22) (2016) 6046-6062.

[53] G.R. Gamble, A. Sethuraman, D.E. Akin, K.E. Eriksson, Biodegradation of lignocellulose in Bermuda grass by white rot fungi analyzed by solid-state ${ }^{13} \mathrm{C}$ nuclear magnetic resonance, Appl. Environ. Microbiol. 60 (1994) 3138-3144.

[54] C. Feng, G. Zeng, D. Huang, S. Hu, M. Zhao, C. Lai, N. Li, Effect of ligninolytic enzymes on lignin degradation and carbon utilization during lignocellulosic waste composting, Process Biochem. 46 (2011) 1515-1520.

[55] F.A. Camargo, L.H. Innocentini-Mei, A.P. Lemes, S.G. Moraes, N. Duran, Processing and characterization of composites of poly (3-hydroxybutyrate-cohydroxyvalerate) and lignin from sugar cane bagasse, J. Compos. Mater. 46 (2012) 417-425.

[56] E. Gomez, L. Ferreras, S. Toresani, Soil bacterial functional diversity as influenced by organic amendment application, Bioresour. Technol. 97 (2006) $1484-1489$ 